\title{
The Effects of Globalization: Hyper Consumption and Environmental Consumer Behavior during the Covid-19 Pandemic
}

\author{
Submitted 21/07/21, 1st revision 10/08/21, 2nd revision 30/09/21, accepted 18/10/21 \\ Mina Angelova ${ }^{1}$, Teofana Dimitrova ${ }^{2}$, Daniela Pastarmadzhieva $^{3}$
}

\begin{abstract}
:
Purpose: The paper examines the effect of the globalization over the consumption and environmental consumer behavior. The period under review is focused on the pandemic situation caused by the COVID-19. The current paper is part of a research that elaborates in three stages. The first stage of this research is presented, and the aim is to identify any indications about the existence of association between the COVID-19 pandemic and the consumption, and between the consumption and the environment protection.

Design/Methodology/Approach: Our initial hypothesis is that the COVID-19 pandemic caused an increase in the consumption and the hyper consumption caused a negative effect on the environmental protection. To test our hypothesis, we used secondary data and comprehensive desk research based upon literature review in the period April 2021 - August 2021. A data set from Eurostat and the Environmental protection index was used.

Findings: The initial results based on the data used show that the COVID-19 pandemic did not increase the consumption and the latter does not affect the environmental protection. As the data we used is limited in time and scope an own methodology was established. The next stages include new data, the elaboration of the survey instruments, namely an own questionnaire, questions for the in-depth interviews and focus groups.

Practical Implications: These findings provide a better understanding of how pandemic situations affect the consumption and environmental consumer behavior.

Originality/Value: This would help governments and companies to improve the value chains management, taking measures to limit the hyper consumption, targeting higher environmental performance.
\end{abstract}

Keyword: Globalization, Hyper Consumption, Environmental Consumer Behavior.

JEL Classification: D12, Q56

Research Type: Research Paper.

Acknowledgments: The research and participation of Mina Angelova and Daniela Pastarmadzhieva is part of a project № KP-06-DK-2/7/2021, funded by Bulgarian National Science Fund. The research and participation of Teofana Dimitrova is part of a project № FP 21-ФИСН-004/2021, financed by Fund "Scientific Research" at the University of Plovdiv Paisii Hilendarski.

\footnotetext{
${ }^{1}$ Associate Professor, Department of Management and Quantitative Methods in Economics, Faculty of Economic and Social Sciences, University of Plovdiv, Bulgaria, mina.angelova@uni-plovdiv.bg ${ }^{2}$ Associate Professor, Department of Marketing and International Economic Relations, Faculty of Economic and Social Sciences, University of Plovdiv, Bulgaria, teofana.dimitrova@uni-plovdiv.bg ${ }^{3}$ Assistant Professor, Department of Political Sciences and National Security, Faculty of Economic and Social Sciences, University of Plovdiv, Bulgaria, daniela.pastarmadzhieva@ uni-plovdiv.bg
} 


\section{Introduction}

There is an ongoing debate about the development and advancement of global value chains by the developed world and its impact on the emerging economies that result in neglect of environmental conditions, environmental irresponsibility, vulnerability amongst employees, exploitative employment relations, increasing employment insecurities, declining wages and conditions, and ethical dilemmas (Arora et al., 2021). Globalization has an extremely rich scope and various consequences on many spheres of public life. Currently, the topic of the COVID-19 pandemic engages the behavior of people from all continents and has economic, health, political, social, psychological, and cultural dimensions. It puts many issues on the agenda, but the most important is the approach that governments must take to overcome the effects of the pandemic.

On the one hand, this approach considers the hyper consumption and environmental consumer behavior specific to each society, but on the other hand it should have a common framework that allows for coherence between countries. This is especially true in the field of economics, where overcoming the effects of COVID-19 depends on many external factors. The considered commitment is of emphasized importance for the member states of the European Union, to which Bulgaria also belongs.

The research object is the citizens behavior, hyper consumption, and environmentally friendly behavior in a pandemic period. From the authors' standpoint hyper consumption is the driving force behind economic growth. And as is widely known, economic growth is the leading political and macroeconomic goal (like an obsession) which is often equaled to "success". But the strive to an endless and uncontrolled growth could cause significant ecologic, cultural, and social harm to civilization instead of providing benefits. Thus, our initial hypothesis is that the COVID-19 pandemic caused an increase in the consumption and the hyper consumption caused a negative effect on the environmental protection.

The aim of the study is to identify any indications about the existence of association between the COVID-19 pandemic and the consumption on one hand and between the consumption and the environment protection on other.

The approaches and methods to test the hypothesis and to achieve the goal include secondary data processing and comprehensive desk research based upon literature review in the period April 2021 - August 2021. A data that we used was from the Eurostat and the Environmental protection index was used. The SPSS v.21 program was applied for statistical analyses. Our study makes several key contributions. First, the literature review gives a theoretical contribution defining the researchers' focus on globalization and hyper consumption. Second, based on a desk review, the elaborated own methodology contributes to the next stages of the research project, namely the online survey, in-depth interviews and focus groups. 
The paper is structured as follows: following the introduction, in the second part different theories, definitions and statements connected with the effects of the globalization, hyper consumption, and environmental consumer behavior are summarized based on a broad literature review. The latter is the framework of the study and is the basis for the third part, which presents the methodology of the research and the results. It consists of opportunity recognition for citizens attitudes toward consumer behavior in the COVID-19 pandemic. The paper closes with conclusions and recommendations for future research in the field of environmental consumer behavior and hyper consumption caused by pandemics and opportunities for transformation national priorities into unified EU strategy.

\section{Literature Review}

\subsection{The Effects of Globalization over the Consumer Behavior}

Some scholars accept globalization as homogenization, with a natural effect of unification in the world, geopolitics for global domination (Marinov, 2018), a kind of Americanization (Popov, 2009). Increasing globalization has a multitude of companies taking advantage of global sourcing through procuring inexpensive raw materials or lower labor costs from developing countries, or with technical expertise from advanced nations to increase its profitability (Dulam et al., 2021). The commented consequences of globalization can be defined mainly as polar, transformation of the postmodern society into information-network, increasing the influence of cross-border companies at the expense of national ones, enhancing stability, democracy and peace, higher competitiveness of enterprises thanks to cheaper resources and new technologies imported from abroad, raising living standards and stimulating the purchasing power of consumers (especially lowincome households), unfair commercial practices by businesses and governments, deepening inequalities and social polarization (European Commission).

International economic networks play an increasingly large role in the entrenchment of economic globalization. Many Europeans are concerned that globalization is leading to inequality, job losses, social injustice and lower environmental, health and privacy standards. Sometimes they also feel that their identity, traditions, and way of life are endangered. These concerns need to be addressed and solutions provided.

The COVID-19 pandemic has a dramatic impact on society, business (entrepreneurship) and government institutions. First, the impact of quarantine and social distancing on mental health and qualities of the human capital play a significant role connected with their professional realization. Second, business organizations may have to regulate measures according to different policy environments. This crisis has reminded business leaders of the importance to adapt and regularly test their response and resilience plans against different disaster scenarios (including pandemics) with their key suppliers and business partners. This includes using these tests to challenge assumptions (such as recovery times) and to 
develop means to measure resilience, response, recovery, and other key capabilities needed to anticipate, withstand, and recover from, and adapt to, adverse conditions. Third, public institutions must force adequate measures to revive the economy. These concepts can provide a framework for a responsible course of action at this pivotal period.

As a rule, during a crisis politicians attempt to direct the effect of the crises in the "desired direction". For instance, after the terrorist attacks in 2001, President George W. Bush called for the American people to "go shopping" (Neuner et al., 2005). During the Great Recession, influential journalist David Leonhardt urges people to keep their spending during a credit crisis, warning them about the dangerous aftermath of the thus formulated by Keynes "paradox of thrift" (Leonhardt, 2009). On the other hand, hyper consumption "shows itself as a hypertrophied and uncontrolled system, a bulimic order leading to extremes and chaos" (Lipovetsky, 2008).

\subsection{Hyper Consumption and the Pro-Environmental Behavior of Individuals}

"Hyper is an idiom that designates the excessive, reaching beyond a norm. It is in the field of signification of superlatives, with a connotation of constant overreaching, of maximum, of extreme conditions" (Rheaume, 2005). Therefore 'hyper' emphasizes experiences of urgency, intensity, instant gratification and especially excess (Makarem, 2014). We share the stance of Schulz (2016) that hyper consumption encapsulates the proposition that market-mediated acquisition and consumption can reach excessive levels with profound repercussions for individuals, society, and the natural world. Various "destructured behavior of pathological and compulsive consumerism" (Lipovetsky, 2008) are significantly displayed in the current consumer era.

Borusiak et al. (2021) state that overconsumption and wasteful resource disposal pose a serious threat to humankind. They try to understand the mechanism of the pro-environmental behavior of individuals expressed both in people's attitudes and in their behavior towards the environment to reduce consumption of single use bottled water and to consume non-bottled water. However, the authors' found that environmental concern is negatively correlated with drinking bottled water.

Scholars pay attention over the pro-environmental behavior for years. Not only the citizens, but also the employees in many business areas are studied because many organizations portray their environmental commitment via different certifications. The same is in the attention of Saleem et al. (2021) who examine the relationship between ethical leadership and employee green behavior (EGB) by the mediating mechanisms of green psychological climate, employees' harmonious environmental passion, and employees' environmental commitment, through the underpinnings of social learning theory. Their results show positive and statistically significant effects of ethical leadership on EGB and state that the leaders' pro-environmental attitude 
contingency strengthens the indirect impact of ethical leadership on it. The findings forward the attention that the leader's vision may ultimately lead to the strategies adopted by the organization and overreact the consumer behavior and hyper consumption in a way the company adopted.

The conducted research and acquired results by scholars give some managerial insights for the promotion of green products and green marketing. To inform consumers about green or eco-friendly products, Nekmahmud and Fekete-Farkas (2020) provide valuable suggestions to companies, marketers, and policymakers for designing green marketing tools such as green advertising, green branding, and ecolabels. Moreover, they state that green marketing can be applied in environmentally friendly ways to satisfy the customers' needs, wants, and demands by protecting the environment and society. Their contributions were helping to change the minds and behavior of the young generation as business leaders and consumers towards the protection of the environment. Trentinaglia De Daverio et al. (2021) worn about policies developing environmentally sustainable products should not forget how consumer preferences for non-strictly environmental attributes might ultimately affect their propensity to buy and pay which is partially connected with the hyper consumption result in different societies and countries.

Several common trends and issues showed corporate social responsibility, emerging markets, political issues, and economic matters as key to global market production. Recommendations signal a strong need for more research that addresses contributive effects in the different economies. Kyove et al. (2021) pay attention that developed countries show more saturated markets than developing countries. Developed country multinationals are likely to use more advanced factors of production to create revenue, whereas developing country multinationals are more likely to use less advanced forms. Globalization has increased productivity in world economies over a long period of time and based on historical trends and growth rates. Kyove et al. (2021) state that international trade is predicted to grow by approximately $50 \%$ in 2021 among multinational enterprises - from developed and developing countriesdespite the COVID-19 crisis.

\section{Conceptual Framework Development}

The review evaluated the globalization impact on environmental consumer behavior via desk research and in-house materials. A scoping literature review was conducted with the following electronic journal databases: Scopus, Web of Knowledge, Science Direct, ProQuest, Sage, Directory of Open Access Journals, and Google Scholar.

To Gilles Lipovetsky the term "hyper consumption" corresponds to "new modernity" which is developed in the second half of the $20^{\text {th }}$ century and coincides with the "civilization of desire" (Lipovetsky, 2008). The features of this concept are clearly identifiable in a capitalist matrix, i.e., the incessant creation of new 
necessities, aggressive marketing techniques urging mindless consumption and an empowerment of demand (Esposti, 2015). Consumption norms become embedded not only culturally, but materially (Freund and Martin, 2008) and the main guideline for a hyper consuming society is "consume or exist".

However, if the levels of consumption that several hundred million of the most affluent people enjoy today were replicated across even half of the roughly 9 billion people projected to be on the planet in 2050, the impact on our water supply, air quality, forests, climate, biological diversity, and human health would be severe (Gardner et al., 2004). One problem that is still currently present is what is the potential scenario - more or less consumption. The idea for less consumption goes even further, finding its expression in the existence of radical movements - antiadvertising, anti-Nike, and anti-GE food activists (Kozinets and Handelman, 2004).

In essence, this resistance against the dominant consumer culture exists before the appearance of a hyper consuming society in the second half of the 1960s. It can be seen in various forms of anti-consumption manifestations and has left a significant trail on consumer research throughout the years (Cherrier, 2009; 2010). Without going deeper into the subject, we will just add that for millions of people around the world living in unthinkable poverty (without access to products which to the western world are considered a given) this debate about more or less consumption is not only non-existent but can even be deemed cynical. It is precisely this portion of the population which needs economic growth to have access to an "acceptable" (according to modern understanding) material existence.

In this current paper we look at impulsive buying, compulsive buying and panic buying as specific effects of a hyper consuming society. To us all three categories of buying are a form of excessive buying behavior (EBB). However, those three forms differ in their motives, frequency, and quickness of fulfilling the purchase.

Excessive buying has been of interest to consumer researchers and public policy advocates for almost three decades (Kukar-Kinney et al., 2016). The COVID-19 pandemic gave further meaning to the topic in lieu of studying the practices of consumption during lockdown and social isolation. Despite the deficit of publications in the field, some of the most significant among them are the works of Billore and Anisimova (2021), Çelik and Divanoğlu (2020), Herjanto et al. (2021), Islam et al. (2021) Untaro and Han (2021).

It is well established that people who are prone to impulsive and compulsive buying display a certain inability to oppose several external stimuli and internal impulses. External stimuli increase an individual's perceived arousal level, which in turn encourages his or her behavioural intention (Islam et al., 2021).

In a period of crisis or pandemic appears the so-called panic buying (PB), described as consumers buying excessive number of products to avoid shortage in the future 
(Shou et al., 2011). It appears suddenly and is based upon a feeling of insecurity and instability as well as a desire to manage a survival threat. Similarly, to impulsive buying, PB is related to emotional state. However, the emotional state of panic buying, and impulsive buying had different motives and functions. Impulsive buying can be influenced by positive emotions, while panic buying is associated with negative emotions as driven consumer behavior (Aquino et al., 2020; Lins and Aquino, 2020).

Therefore, because of a perceived level of risk and insecurity, PB may appear among different types of consumers - even among those who in the usual situation would follow a normal buying pattern. The panic buying behaviour due to COVID-19 outbreak occurred in several countries such as Brazil, Australia, New Zealand, and America. In fact, panic buying had occurred before the Covid-19 outbreak. Historically, panic buying behavior is not a new phenomenon as it began during the Spanish flu outbreak in 1918 (Eva et al., 2020).

Despite the anticipated negative influence of the forms of excessive buying behavior we expect that through the moderation role of public awareness and government regulations the impact of this negative influence could be reduced. Our assumption is based on previous research which confirm the government's vital role in creating an environment for sustainable consumption as well as instill SCB (Martinez et al., 2015; Yahya, 2013; 2015). In Figure 1 we present our idea for a concept frame for researching the potential connection between EBB and SCB based on the literature review performed.

Figure 1. Excessive Buying and Sustainable Consumer Behaviour Framework

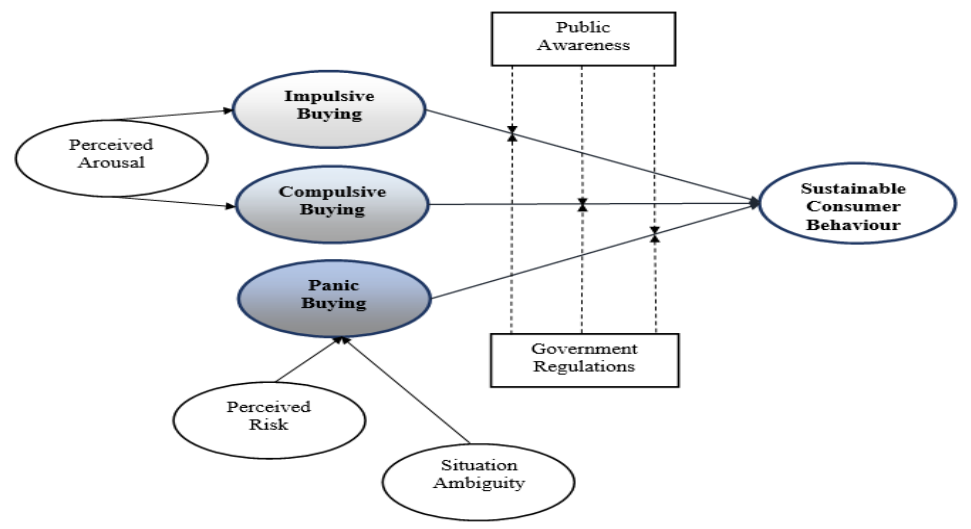

Source: Author's model.

The following proposition researchers can draw which were already highlighted in the conceptual framework later.

P1: Perceived arousal will have a positive impact on impulse buying.

P2: Perceived arousal will have a positive impact on compulsive buying. 
P3: Perceived risk will have a positive impact on panic buying.

P4: Situation ambiguity will have a positive impact on panic buying.

P5: Consumers' impulsive buying will negatively influence their sustainable consumer behaviour.

P6: Consumers' compulsive buying will negatively influence their sustainable consumer behaviour.

P7: Consumers' panic buying will negatively influence their sustainable consumer behavior.

P8: Public awareness will moderate relationship between impulsive buying, compulsive buying, panic buying and sustainable consumer behavior.

P9: Government regulations will moderate relationship between impulsive buying, compulsive buying, panic buying and sustainable consumer behavior.

\section{Methods and Results}

As stated at the beginning of this paper through the current research we tried to identify any association between the COVID-19 pandemic and the hyper consumption on one hand. In the study process we faced several challenges, which present the limitations to the research.

Our main interest initial was the hyper consumption and in particular the panic consumption because the panic buying is driven by negative emotions and the COVID-19 pandemic is associated with such emotions. There are studies in this area, which are cases from specific context (Hall et al., 2021; Keane and Neal, 2021; O'Connell et al., 2020) and there is no world data available free on this topic. Thus, on this initial stage of the research, we focus on the overall consumption, measured by Domestic material consumption per capita (tons per capita) ${ }^{4}$.

As this data is collected by Eurostat and has a limited coverage of countries, we decided to focus on the member states of the European Union. We were unable to find data, available for wide range of countries worldwide and this was the second challenge. The availability of data is the limitation which made us focus on the EU only. The other association, which we intended to identify is between the consumption and the environmental protection. As the purpose of this research was to make general conclusion as a starting point, we used the Environmental

\footnotetext{
${ }^{4}$ The indicator is defined as the total amount of material directly used in an economy and equals direct material input (DMI) minus exports. DMI measures the direct input of materials for the use in the economy. DMI equals domestic extraction (DE) plus imports. For the 'per capita' calculation of the indicator the average population is used (the arithmetic mean of the population on 1st January of two consecutive years). Domestic Material Consumption (DMC) is based on the Economy-wide Material Flow Accounts (EW-MFA). The theory of Economy-wide material flow accounts includes compilations of the overall material inputs into national economy, the changes of material stock within the economy and the material outputs to other economies or to the environment. EW-MFA covers all solid, gaseous, and liquid materials, except water and air. Water included in products is included.
} 
Performance Index, performed by Yale University Center for Environmental Law \& Policy. The index measures the environmental performance of the countries in every two years. Thus, we had this limitation in identifying association to not having data for every year. Thus, we focused on 2010, 2012, 2014, 2016, 2018 and 2020.

The results show an interesting trend. In the period 2010-2016 it seems that there is association between the average consumption of the EU member states and their average environmental performance index (Figure 2). However, the trend is different in 2018 and 2020. Furthermore, the results show the average EU consumption in 2020 compared to 2018 decreased (Figure 2). This is an indication to assume that the COVID-19 pandemic didn't increased the consumption. However, the new data of 2021 will show if this trend is stable or not.

Figure. 2. Consumption, measured by Eurostat's Domestic material consumption per capita (tons per capita) and EPI

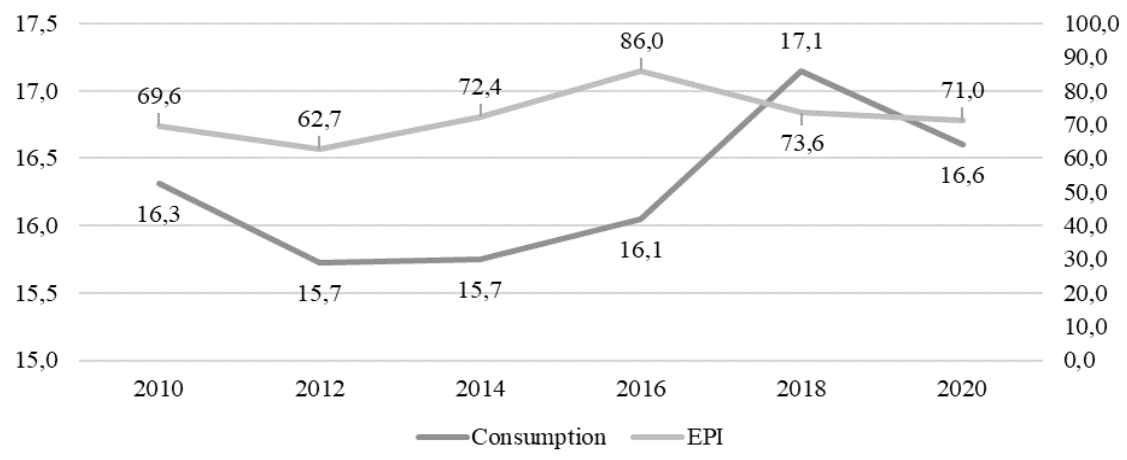

Source: Eurostat, Environmental Performance Index.

To identify a statistical association, we created a database in IBM SPSS Statistics. It consisted of the variables, presented in Table 1.

Table 1. The SPSS database, created for the purposes of the current study

\begin{tabular}{ll}
\hline Variable & Values \\
\hline Country & EU member states \\
\hline Year & $2010,2012,2014,2016,2018,2020$ \\
\hline $\begin{array}{l}\text { Consumption (Eurostat Domestic } \\
\text { material consumption per capita) }\end{array}$ & The value for each country and year \\
\hline EPI (Environmental Performance Index) & The value for each country and year \\
\hline
\end{tabular}

Source: Authors' database.

Both variables, which we wanted to test, are on a strong scale. Thus, we attempted to use a one-way regression analysis. We used consumption as a factor variable and EPI as a resultant. To select the most relevant model for regression analysis, we first made the scatter plot. The scatter plot does not give grounds to determine unambiguously which model would be the best and to be sure we check all models. 
Figure. 3. Scatter plot for consumption and EPI, performed in SPSS (Dependent Variable: Environmental Performance Index, Independent Variable: Eurostat Domestic material consumption per capita)

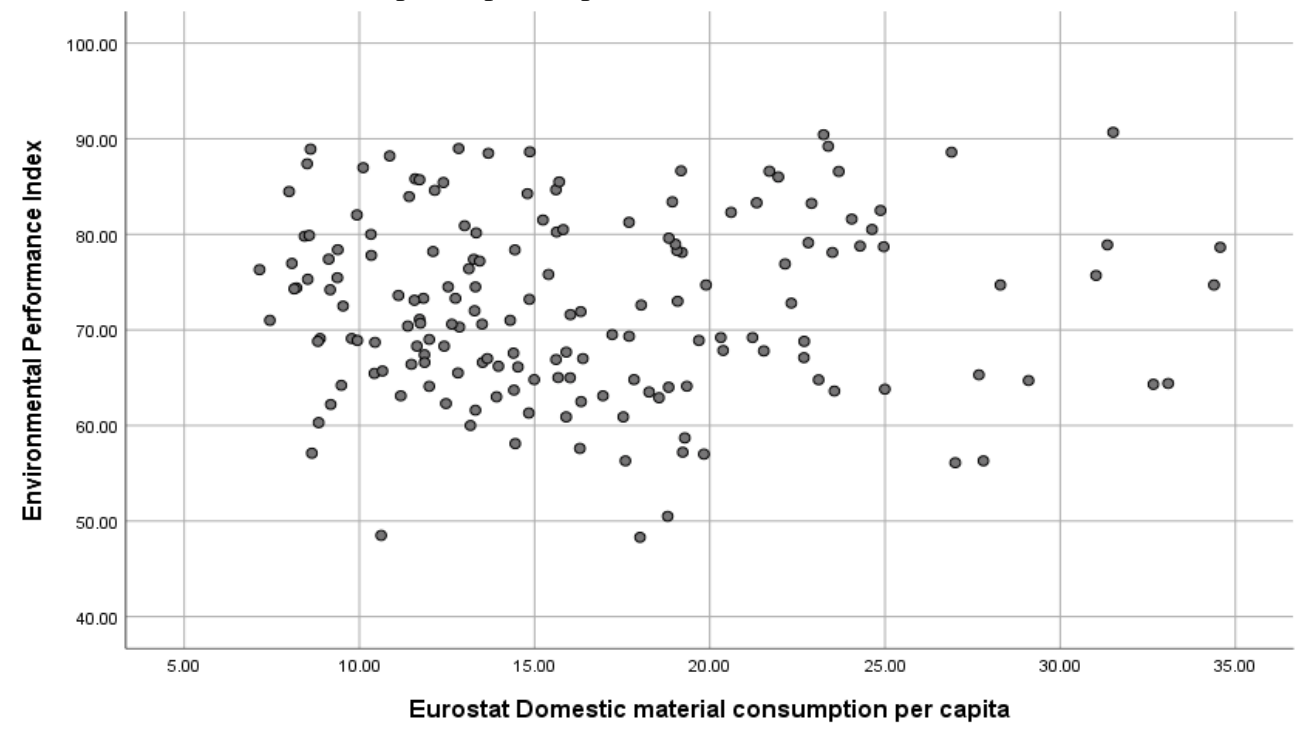

Source: Authors' calculations/

To determine the adequate models, we must compare the value of Sig with the probability of error $\alpha=0.05$. If Sig $>\alpha$ the model is not adequate, and when $\operatorname{Sig}<\alpha$, then the model is adequate. The results in Table 2 . we show that in all models the value of Sig is higher than $\alpha=0.05$, therefore there are no adequate models.

Table 2. Model Summary and Parameter Estimates (Dependent Variable: Environmental Performance Index, Independent Variable: Eurostat Domestic material consumption per capita)

\begin{tabular}{|c|c|c|c|c|c|c|c|c|c|}
\hline \multirow[b]{2}{*}{ Equation } & \multicolumn{5}{|c|}{ Model Summary } & \multicolumn{4}{|c|}{ Parameter Estimates } \\
\hline & Square & $\mathrm{F}$ & df1 & df2 & Sig. & Constant & b1 & b2 & b3 \\
\hline Linear & .000 & .040 & 1 & 165 & .843 & 72.107 & .023 & & \\
\hline Logarithmic & .000 & .021 & 1 & 165 & .884 & 73.268 & -.288 & & \\
\hline Inverse & .002 & .251 & 1 & 165 & .617 & 71.478 & 14.336 & & \\
\hline Quadratic & .011 & .912 & 2 & 164 & .404 & 78.556 & -.754 & .020 & \\
\hline Cubic & .026 & 1.454 & 3 & 163 & .229 & 98.969 & -4.469 & .224 & -.003 \\
\hline Compound & .000 & .009 & 1 & 165 & .927 & 71.702 & 1.000 & & \\
\hline Power & .000 & .067 & 1 & 165 & .795 & 73.302 & -.007 & & \\
\hline $\mathrm{S}$ & .002 & .375 & 1 & 165 & .541 & 4.258 & .247 & & \\
\hline Growth & .000 & .009 & 1 & 165 & .927 & 4.273 & .000 & & \\
\hline Exponential & .000 & .009 & 1 & 165 & .927 & 71.702 & .000 & & \\
\hline Logistic & .000 & .009 & 1 & 165 & .927 & .014 & 1.000 & & \\
\hline
\end{tabular}

Source: Authors' calculations. 


\section{Conclusion}

According to the performed study we share the view of Dhandra (2019), Nguyen and Paswan (2013), Zafar et al. (2021) that hyper consumption is unsustainable, and something needs to be done. In this light, one of the challenges is to inspire the consumers to engage in sustainable behavior. This task would possibly face significant hurdles throughout the various forms of excessive buying conduct.

Among the effects of the unstable models of consumption we look for generating large quantities of food leftovers and waste, obesity, credit debt, lack of savings, buying new electrical devices due to unwillingness to do repairs, hyper automobility. The initial results based on the freely available data on macro level show that the COVID-19 pandemic did not increase the consumption and the latter does not affect the environmental protection. As the data we used is limited in time and scope an own methodology was established. The next stages include new data, covering 2021 as well and widens the range of countries. Furthermore, the methodology includes the elaboration of the survey instruments, namely an own questionnaire, questions for the in-depth interviews and focus groups on the case of Bulgaria.

Author Contributions: Introduction, M.A.; Literature Review, M.A.; Conceptual Framework, T.D.; Methods and Results, D. P.; Conclusions, M.A. and D. P.; Proof Reading, M.A. All authors have read and agreed to the published version of the manuscript.

Conflicts of Interest: The authors declare no conflict of interest.

\section{References:}

Aquino, S.D., Natividade, J.C., Lins, S.L.B. 2020. Validity Evidences of the Buying Impulsiveness Scale in the Brazilian Context. Psico-USF, 25(1), 15-25. https://doi.org/10.1590/1413-82712020250102.

Arora, A., Arora, A., Anyu, J., McIntyre, J.R. 2021. Global Value Chains' Disaggregation through Supply Chain Collaboration, Market Turbulence, and Performance Outcomes. Sustainability, 13, 4151. https://doi.org/10.3390/su13084151.

Borusiak, B., Szymkowiak, A., Pierański, B., Szalonka, K. 2021. The Impact of Environmental Concern on Intention to Reduce Consumption of Single-Use Bottled Water. Energies, 14, 1985. https://doi.org/10.3390/en14071985.

Cachero-Martínez, S. 2020. Consumer Behaviour towards Organic Products: The Moderating Role of Environmental Concern. J. Risk Financial Management, 13, 330. https://doi.org/10.3390/jrfm13120330.

Caniëls, M.C.J., Lambrechts, W., Platje, J., Motylska-Kuźma, A., Fortuński, B. 2021. 50 Shades of Green: Insights into Personal Values and Worldviews as Drivers of Green Purchasing Intention, Behaviour, and Experience. Sustainability, 13, 4140. https://doi.org/10.3390/su13084140.

Cherrier, H. 2009. Anti-consumption discourses and consumer-resistant identities. Journal of Business Research, 62(2), 181-190. https://doi.org/10.1016/j.jbusres.2008.01.025.

Cherrier, H. 2010. Custodian Behavior: A Material Expression of Anti-Consumerism. Consumption Markets and Culture, 13(3), 259-272. https://doi.org/10.1080/10253861003786983. 
Dhandra, T.K. 2020. Does self-esteem matter? A framework depicting role of self-esteem between dispositional mindfulness and impulsive buying. Journal of Retailing and Consumer Services, 55, https://doi.org/10.1016/j.jretconser.2020.102135.

Dulam, R., Furuta, K., Kanno, T. 2021. Consumer Panic Buying: Realizing Its Consequences and Repercussions on the Supply Chain. Sustainability, 13, 4370. https://doi.org/10.3390/su13084370.

Emerson, J.W., Hsu, A., Levy, M.A., de Sherbinin, A., Mara, V., Esty, D.C., Jaiteh, M. 2012. 2012 Environmental Performance Index and Pilot Trend Environmental Performance Index. New Haven: Yale Center for Environmental Law and Policy.

Emerson, J., Esty, D.C., Levy, M.A., Kim, C.H., Mara, V., de Sherbinin, A., Srebotnjak, T. 2010. 2010 Environmental Performance Index. New Haven: Yale Center for Environmental Law and Policy.

Esposti, P.D. 2015. Hyper consumption. In: D.T. Cook, J.M. Ryan (Eds.). The Wiley Blackwell Encyclopedia of Consumption and Consumer Studies. John Wiley \& Sons, Ltd. https://doi.org/10.1002/9781118989463.wbeccs147.

European Commission Commission launches reflection on harnessing globalization. https://ec.europa.eu/commission/presscorner/detail/bg/IP 17 1230.

Eurostat (n.d.) Domestic material consumption per capita. https://data.europa.eu/data/datasets/pwzdbpy2plucl8qihmofa?locale=en.

Eva, N., Saputra, D.R., Wulandari, D.A., Yahya, F.A., Annisa, W. 2020. Panic-Buying Behavior During the Covid-19 Outbreak: A Cross-Cultural Psychological Study. In: International Conference of Psychology, KnE Social Sciences, 80-87. doi: 10.18502/kss.v4i15.8192.

Freund, P., Martin, G. 2008. Fast Cars/Fast Foods: Hyperconsumption and its Health and Environmental Consequences. Social Theory \& Health, 6(4), 309-322. doi: $\underline{10.1057 / \text { sth.2008.10. }}$

Gardner, G., Assadourian, E., Sarin, R. 2004. The state of consumption today. In: L. Starke (Ed.), Stare of the World. W.W. Norton, 3-21.

Grima, S., Dalli Gonzi, R., Thalassinos, I.E. 2020. The Impact of COVID-19 on Malta and its Economy and Sustainable Strategies. Available at: https://ssrn.com/abstract=3644833.

https://anzctr.org.au/Trial/Registration/TrialReview.aspx?ACTRN=12620000636954.

Hall, C.M., Fieger, P., Prayag, G., Dyason, D. 2021 Panic Buying and Consumption Displacement during COVID-19: Evidence from New Zealand. Economies, 9(46). https:// doi.org/10.3390/economies9020046.

Hsu, A., Esty, D., Levy, M., de Sherbinin, A. et al. 2016. The 2016 Environmental Performance Index Report. New Haven, CT: Yale Center for Environmental Law and Policy. https://doi.org/10.13140/RG.2.2.19868.90249.

Hsu, A., Emerson, J., Levy, M., de Sherbinin, A., Johnson, L., Malik, O., Schwartz, J., Jaiteh., M. 2014. The 2014 Environmental Performance Index. New Haven, CT: Yale Center for Environmental Law and Policy. https://www.epi.yale.edu.

Islam, T., Pitafi, A.H., Arya, V., Wang, Y., Akhtar, N., Mubarik, S., Xiaobei, L. 2021. Panic buying in the COVID-19 pandemic: A multi-country examination. Journal of Retailing and Consumer Services, 59. https://doi.org/10.1016/j.jretconser.2020.102357.

Johnson, E., Plepys, A. 2021. Product-Service Systems and Sustainability: Analysing the Environmental Impacts of Rental Clothing. Sustainability, 13, 2118. https://doi.org/10.3390/su13042118. 
Keane, M., Neal, T. 2021. Consumer panic in the COVID-19 pandemic. Journal of econometrics, 220(1), 86-105. https://doi.org/10.1016/j.jeconom.2020.07.045.

Khan, S., Rabbani, R.M., Thalassinos, I.E., Atif, M. 2020. Corona Virus Pandemic Paving Ways to Next Generation of Learning and Teaching: Futuristic Cloud Based Educational Model. Available at SSRN: https://ssrn.com/abstract=3669832.

Kozinets, R.V., Handelman, J.M. 2004. Adversaries of Consumption: Consumer Movements, Activism, and Ideology. Journal of Consumer Research, 31(3), 691704. https://doi.org/10.1086/425104.

Kukar-Kinney, M., Scheinbaum, A.C., Schaefers, T. 2016. Compulsive buying in online daily deal settings: An investigation of motivations and contextual elements. Journal of Business Research, 69, 691-699.

Kyove, J., Streltsova, K., Odibo, U., Cirella, G.T. 2021. Globalization Impact on Multinational Enterprises. World, 2, 216-230. https://doi.org/10.3390/world2020014.

Leonhardt, D. 2009. To Spend or to Save? Trick Question. The New Work Times. https://www.nytimes.com/2009/02/11/business/economy/11leonhardt.html.

Lin, K., Ayaz, A., Wang, L. 2021. Measuring the Feature of "The Global”: A Framework for Analyzing the Global City Ranking. Sustainability, 13, 4084. https://doi.org/10.3390/su13084084.

Lins, S., Aquino, S. 2020. Development and initial psychometric properties of a panic buying scaleduring COVID-19 pandemic. Heliyon. https://doi.org/10.1016/j.heliyon.2020.e04746.

Lipovetsky, G. 2008. Paradoksalnoto shtastie: Opit varhu obshtestvoto na hiperkonsumirane. L. Dimitrova, Trans., Riva.

Marinov, G (2018) Globalization as a geopolitics of global domination Journal Geopolitics, 4, https://geopolitica.eu/2018/170-broy-4-2018/2871-globalizatsiyata-katogeopolitika-za-globalna-dominatsiya [04.03.21] available in Bulgarian.

Marinov, V. 2009. On the global governance of the International economic system. Yearbook of the UNWE, 117-178, available in Bulgarian.

Martinez, C.P., Castaneda, M.G., Marte, R.B., Roxas, B. 2015. Effects of institutions on ecological attitudes and behaviour of consumers in a developing Asian country: the case of the Philippines. International Journal of Consumer Studies, 39(6), 575-585. https://doi.org/10.1111/ijcs.12188.

Muranko, Ż., Tassell, C., Zeeuw van der Laan, A., Aurisicchio, M. 2021. Characterisation and Environmental Value Proposition of Reuse Models for Fast-Moving Consumer Goods: Reusable Packaging and Products. Sustainability, 13, 2609. https://doi.org/10.3390/su13052609.

Nekmahmud, M., Fekete-Farkas, M. 2020. Why Not Green Marketing? Determinates of Consumers' Intention to Green Purchase Decision in a New Developing Nation. Sustainability, 12, 7880. https://doi.org/10.3390/su12197880.

Nguyen, T.D., Paswan, A.K. 2013. Self-control and Sustainable Consumer Behavior. AMS, 1-21. https://www.researchgate.net/publication/282818541.

NorMoE. 1994. Report of the Symposium on Sustainable Consumption, 19-20 January, Oslo, Norway. Norwegian Ministry of the Environment.

O'Connell, M., De Paula, Á., Smith, K. 2020 Spending dynamics and panic buying during the COVID-19 first wave. https://voxeu.org/article/spending-dynamics-and-panicbuying-during-covid-19-first-wave.

Pérez-Pons, M.E., Plaza-Hernández, M., Alonso, R.S., Parra-Domínguez, J., Prieto, J. 2021. Increasing Profitability and Monitoring Environmental Performance: A Case Study 
The Effects of Globalization: Hyper Consumption and Environmental Consumer Behavior during the Covid-19 Pandemic

in the Agri-Food Industry through an Edge-IoT Platform. Sustainability, 13, 283. https://doi.org/10.3390/su13010283.

Popov, N. 2009. Globalization and Regionalization, UP Neofit Rilski Blagoevgrad, available in Bulgarian.

Saleem, M., Qadeer, F., Mahmood, F., Han, H., Giorgi, G., Ariza-Montes, A. 2021. Inculcation of Green Behavior in Employees: A Multilevel Moderated Mediation Approach. Int. J. Environ. Res. Public Health, 18, 331. https://doi.org/10.3390/ijerph18010331.

Shou, B., Xiong, H., Shen, Z.M. 2011. Consumer Panic Buying and Fixed Quota Policy. Consumer Panic Buying and Fixed Quota Policy, 1-38.

Śmiglak-Krajewska, M., Wojciechowska-Solis, J., Viti, D. 2020. Consumers’ Purchasing Intentions on the Legume Market as Evidence of Sustainable Behaviour. Agriculture, 10, 424. https://doi.org/10.3390/agriculture10100424.

Steiner, G., Zenk, L., Schernhammer, E. 2020. Preparing for the Next Wave of COVID-19: Resilience in the Face of a Spreading Pandemic. Int. J. Environ. Res. Public Health, 17, 4098. https://doi.org/10.3390/ijerph17114098.

Trentinaglia De Daverio, M.T., Mancuso, T., Peri, M., Baldi, L. 2021. How Does Consumers' Care for Origin Shape Their Behavioural Gap for Environmentally Friendly Products?. Sustainability, 13, 190. https://doi.org/10.3390/su13010190

Wendling, Z.A., Emerson, J.W., de Sherbinin, A., Esty, D.C., et al. 2020. 2020 Environmental Performance Index. New Haven, CT: Yale Center for Environmental Law \& Policy. epi.yale.edu https://doi.org/10.13140/RG.2.2.21182.51529.

Wendling, Z.A., Emerson, J.W., Esty, D.C., Levy, M.A., de Sherbinin, A., et al. 2018. 2018 Environmental Performance Index. New Haven, CT: Yale Center for Environmental Law \& Policy. https://epi.envirocenter.yale.edu/node/36476.

Xu, H., Hsu, W.L., Lee, Y.C., Chern, T.Y., Luo, S.W. 2020. Information Application of the Regional Development: Strategic Couplings in Global Production Networks in Jiangsu, China. Information, 11, 420. https://doi.org/10.3390/info11090420.

Xue, J., Rasool, Z., Nazar, R., Khan, A.I., Bhatti, S.H., Ali, S. 2021. Revisiting Natural Resources - Globalization-Environmental Quality Nexus: Fresh Insights from South Asian Countries. Sustainability, 13, 4224. https://doi.org/10.3390/su13084224.

Yahya, W.K., Hashim, N.H., Musa, N.D. 2013. Government and environmental friendly consumer behavior. Seminar Kebangsaan MACFEA ke 17, Malaysia, 470-483. https://www.researchgate.net/publication/280918814.

Yahya, W.K., Hashim, N.H., Musa, N.D. 2015. Environmentally Friendly Consumer Behavior in Malaysia, 19th MACFEA National Seminar, Putrajaya, Malaysia, 264273. https://www.researchgate.net/publication/284713704.

Yahya, W.K., Musa, N.D., Hashim, N.H. 2016. Understanding Environmental Friendly Consumer Behavior. Regional Conference on Science, Technology and Social Sciences (RCSTSS), Malaysia, 909-921. https://www.researchgate.net/publication/280918759.

Zafar, A.U., Shen, J., Shahzad, M., Islam, T. 2021. Relation of impulsive urges and sustainable purchase decisions in the personalized environment of social media. Sustainable Production and Consumption, 25, 591-603. https://doi.org/10.1016/j.spc.2020.11.020.

Zuzańska-Żyśko, E. 2021. Role of Advanced Producer Services Shaping Globalization Processes in a Post-Industrial Region: The Case of the Górnośląsko-Zagłębiowska Metropolis. Sustainability, 13, 211. https://doi.org/10.3390/su13010211. 